\title{
仮想観客インタフェースに会話活性度推定モデルを付与した 場の盛り上がり支援システム*
}

\author{
瀬島 吉裕 ${ }^{* 1}$, 渡辺 富夫 ${ }^{* 2}$, 石井 裕 $^{* 3}$
}

\section{An Interaction-Activated Communication Support System Using a Virtual Audience with an Estimated Model of Conversational Activity}

\author{
Yoshihiro SEJIMA*1, Tomio WATANABE and Yutaka ISHII \\ ${ }^{* 1}$ Graduate School of Science and Engineering, Yamaguchi University \\ 2-16-1 Tokiwadai, Ube, Yamaguchi, 755-8611, Japan
}

Previously, we developed an embodied virtual communication system (EVCOS) for human interaction analysis by synthesis, and confirmed the importance of embodied sharing in avatar-mediated communication. In this paper, we analyze human interaction and communication in interaction-activated conversation for supporting avatar-mediated communication by using EVCOS, and we propose a model for estimating conversational activity on the basis of this analysis. Further, we develop an interaction-activated communication support system for enhancing embodied interaction and communication by applying the proposed model to a virtual audience comprising interactive CG objects. In this system, the virtual audience generates entrained nodding responses as well as dynamic movements based on the estimated conversational activity during the interaction-activated communication period. The effectiveness of the system is demonstrated by means of sensory evaluations and behavioral analysis of 20 pairs of subjects involved in avatarmediated communication.

Key Words : Human Interface, Man-Machine-Communication, Emotion, Kansei and Embodiment, Human Engineering, Virtual Reality

\section{1. は じめ に}

近年 , 情報機械の飛躍的な性能向上やネットワークの普及により，情報機械を媒体とした新たなコミュニケー ションサービスが提供され，人と人とのコミュニケーション形態が多樣化している ${ }^{(1)}$. とくに , メタバースやオ ンラインゲーム等, ネットワーク上の $3 \mathrm{D}$ バーチャル空間でアバタ (自己の分身となる CG キャラクタ) を介し てコミュニケーションを行うシステムが実用化され，多くのユーザがコミュニケーションツールとして利用して いる ${ }^{(2)}$.また，アバタに身体性を付与したコミュニケーション支援システムの開発 ${ }^{(3)(4)}$ や身体的対話ェージェン $卜^{(5)(6)}$ の検討が進められており，樣々な研究が精力的に行われている．しかしながら，このようなコミュニケー ションシステムでは, 場とのかかわりや互いの身体性の共有が不十分でインタラクションが把握しにくく，場の盛 り上がりや一体感が創出されにくい, 本来, 人と人とが行うコミュニケーションでは, 単に言葉によるバーバル情 報だけでなく，うなずきや身振り・手振り，周辺言語などの言葉によらないノンバーバル情報が引き込むことで， 相互の身体性が共有され，円滑なコミュニケーションが行われている ${ }^{(7)}$. この身体性の共有が場の盛り上がりや 一体感を生み, 人とのかかわりを実感させている .

著者らはこれまでに, アバタを介したコミュニケーションを支援するために, アバタの周囲に配置されている CG オブジェクトがあたかも観客のようにコミュニケーション場にかかわる仮想観客インタフェースを開発してい

* 原稿受付 2012 年 4 月 16 日

*1 正員, 山口大学大学院 理工学研究科情報・デザイン工学専攻 († 755-8611 山口県宇部市常盤台 2 丁目 16-1)

*2 正員, フェロー, 岡山県立大学 情報工学部情報システム工学科 (广 719-1197 岡山県総社市窪木 111)

*3 岡山県立大学 情報工学部 情報システム工学科

E-mail: sejima@yamaguchi-u.ac.jp 
る ${ }^{(8)}$.このインタフェースでは, 観客として壁一面に配置されたひまわり型 CG オブジェクトが対話者の発話音 声に対して聞き手としてうなずき動作や身体動作などの引き込み動作を行い，かかわりの場を創出する .このイ ンタフェースを用いてコミュニケーション実験を行った結果，対話しやすさが向上するなど，人とのインタラク ション支援に有効であることを示している．

一方，対面コミュニケーションでは，うなずきのような引き込み反応だけでなく，場の盛り上がりがコミュニ ケーションの促進に重要な役割を果たしている ${ }^{(9)}$. アバタを介したコミュニケーションにおいても，場の盛り上 がりを反映することで， 円滑なコミュニケーションが実現されることが報告されている．例えば，Björn らは，会 話の状況や盛り上がりなどの音声情報を基に, アバタの手のジェスチャ動作を变化させることで, 場の盛り上がり が反映可能であることを示している ${ }^{(10)}$. また, 前田らは, 「場の活性度」を自動的に推測する手法の確立を目指し て，手の動き等のジェスチャから推定する手法を提案している ${ }^{(11)}$.さらに，守屋らはアバタの自動制御手法の開 発を目的として, 対話者のオーバラップや平均発話潜時や発話率から個人の活性度と場の活性度を推定する会話 活性度の推定を検討している ${ }^{(12)}$.このようなシステムでは, 数理モデルから場の盛り上がりを推定し, アバタの 手の動作や身体動作を自動生成している．しかしながら，場の共有や相互の一体感を強めるためには，単にアバ タの動作制御だけでなく，アバタを含めた場全体とのかかわりを実感できるシステムを設計する必要がある．光 のため，これまで開発してきた仮想観客インタフェースを用いて場の盛り上がり行動特性に基づいた身体動作を 表現することで, コミュニケーション場に一体感がもたらされ，人との身体的インタラクションが促進されると 期待される .

そこで本研究では，アバタを介したコミュニケーションを解析できる身体的バーチャルコミュニケーションシス テム $\operatorname{EVCOS}{ }^{(13)}$ を用いて, コミュニケーションにおける場の盛り上がり特性を解析し, 弚の解析結果に基づいて 会話活性度を推定する会話活性度推定モデルを提案している.さらに，提案モデルをこれまで開発してきた仮想観 客インタフェースに適用し，会話活性度推定モデルに基づく場の盛り上がり支援システムを開発している . 開発し たシステムを用いてコミュニケーション実験を行い，提案モデルおよび開発したシステムの有効性を示している．

\section{2. 場の盛り上がり特性解析実験}

本研究では，身体動作や音声等の各種インタラクションが活性化した状態を「場の盛り上がり」として定義し， アバタを介したコミュニケーション時における場の盛り上がり特性を解析するために，身体的バーチャルコミュニ ケーションシステム EVCOS を用いて 2 者間コミュニケーション実験を行った .

\section{$2 \cdot 1$ 身体的バーチャルコミュニケーションシステム EVCOS}

EVCOS は, 自己と相手のアバタである VirtualActor (VA)をバーチャル空間に配置し，同一空間内で対面コミュ ニケーションを実現している.対話者は互いのVA を観察しながらコミュニケーションを行うことで, 相互の身体 性を共有することができる ${ }^{(13)}$. EVCOS では，磁気センサ (POLHEMUS FASTRAK) を用いて対話者の身体動作 を計測し，リアルタイムにVA に反映すると同時にハードディスクに記録している .このときの描画速度は 30fps である.EVCOS を用いた対話場面例を図 1 に示す．この場面は，対話配置実験により最も好まれた対話場面であ り，自己VA と相手 VA が対面している樣子を自己VAの後方から確認できる ${ }^{(14)}$.

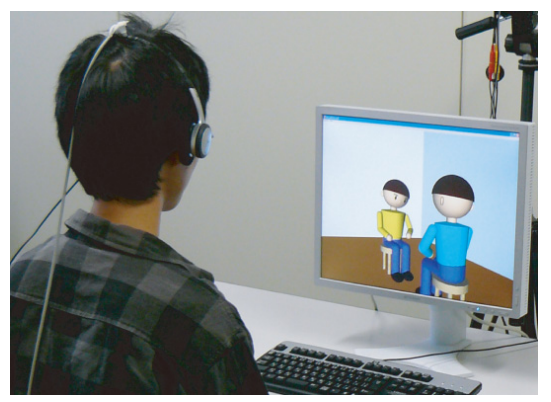

Fig. 1 Communication scene using EVCOS.

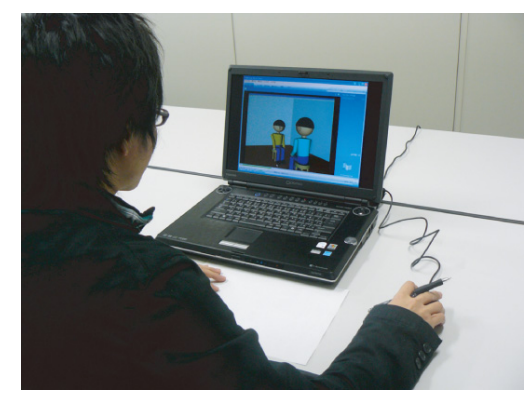

Fig. 2 Selecting scene of interaction-activated communication using video. 


\section{$2 \cdot 2$ 実験方法}

実験は 2 人 1 組で行い，被験者には光れ光れ別室でディスプレイを見ながら対話を行わせた．本実験では，自 然に対話が盛り上がると想定される日常対話を対象として自由対話実験を行った．被験者は友人の間柄で，21 歳 〜24 歳までの男子学生 4 組 8 人であった .

実験手順は，まず 3 分間システムを試用させた後 , 自由対話実験を 3 分間行った . このとき , ディスプレイに表 示される映像と相互の音声を対話の樣子として録画した . 実験直後 , 図 2 のようにノート PCを用いて Microsoft WindowsMediaPlayer により録画した動画を対話者自身に視聴させた . 本研究では，会話全体に対する盛り上がり ではなく，時系列での盛り上がりを対象としているため，個人の主観に基づいて場が盛り上がっていると感じる開 始時刻と終了時刻を 1 秒単位で記録させた . 動画の視聴回数は無制限にし，何度でも再生可能とした．また，場 の盛り上がり区間は複数選定してよいものとした . なお , 対話における場の盛り上がりの判定手法として , 個人 の主観評価による判定の妥当性か認められていることから ${ }^{(15)}$, 本研究では主観評価を採用した．とくに，主観評 価の信頼性の観点から，場の盛り上がりの段階的な程度ではなく，盛り上がっている状態」「盛り上がっていない 状態」の 2 值として回答させた . 次に, 対話に参加していない被験者 6 人に対して同じ動画を視聴させ , 同樣の 方法で場の盛り上がり区間の時刻を記録させた .この手順で，全 4 組の動画に対して，対話者を含む合計 8 人の 被験者が場の盛り上がり区間の選定を行った．

\section{$2 \cdot 3$ 場の盛り 上がり特性解析}

まず, 実験における場の盛り上がり区間を特定するために，被験者が実験動画から場が盛り上がっていると判断 した区間を ON，光うでない区間を OFF として場の盛り上がりの 2 值化を行った . 人数を縦軸として，全 4 組の 2 值化した場の盛り上がりを加算した時系列データを「場の盛り上がり加算波形」として図 3 に示す.斜線の区間 は，実際に対話を行った両被験者が共に場の盛り上がりを感じた時間帯を示している．また，図中の矢印は両者 が笑い合っている区間を示している．図より，両対話者本人が場の盛り上がりを感じる区間に対して，対話不参 加者においても同樣に判定される傾向が見られる . また，実験動画から場の盛り上がりを感じる区間を確認した 結果，主に被験者同士が笑い合っている場面が確認された .ここで，全被験者が選定した 1 区間当たりの場の盛 り上がりの平均時間は 29 秒であり, 最小時間は 5 秒であった .このことから，場の盛り上がりは瞬間的なもので

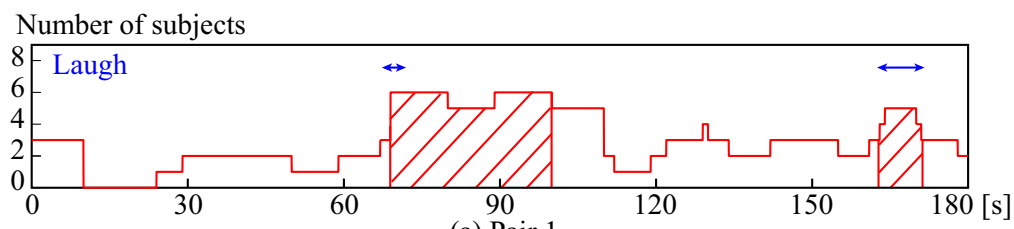

(a) Pair 1 .

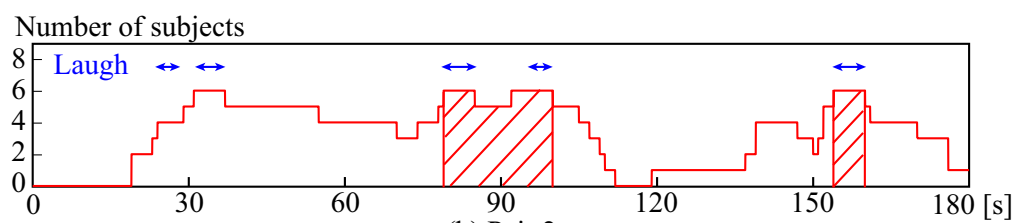

(b) Pair 2.

Number of subjects

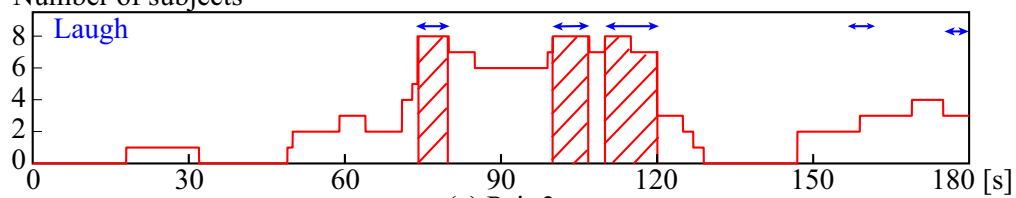

(c) Pair 3.

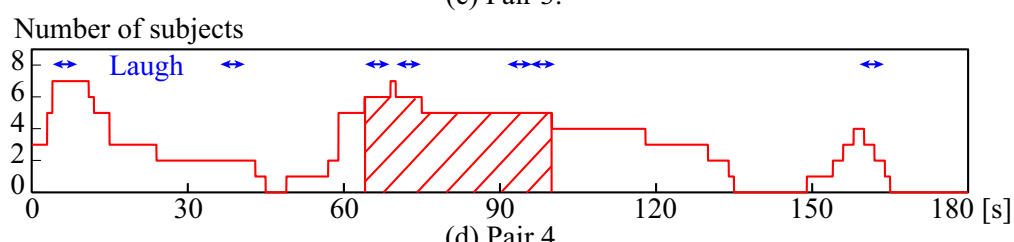

(d) Pair 4.

Fig. 3 Change in the interaction-activated communication with time, based on the number of subjects by whom the scene is subjectively selected as the activated communication scene. 


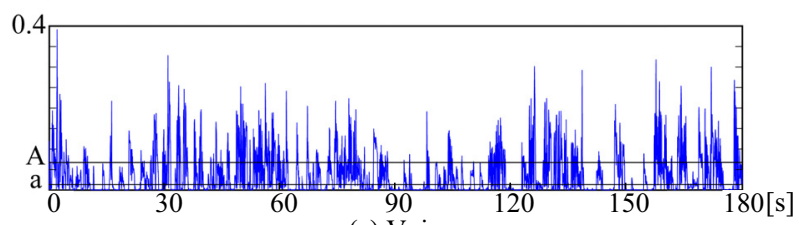

(a) Voice

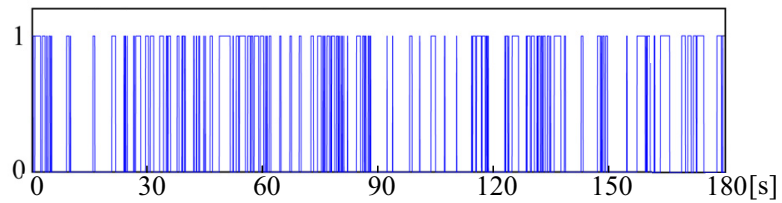

(b) Binary (Threshold A)

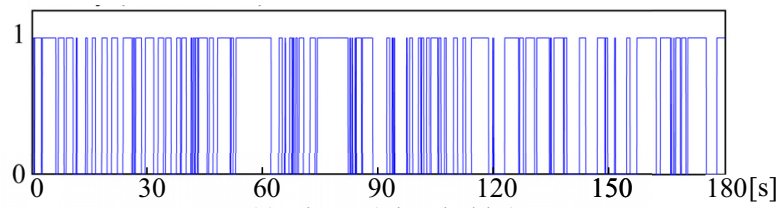

(c) Binary (Threshold a)

Fig. 4 Example of binary voices.
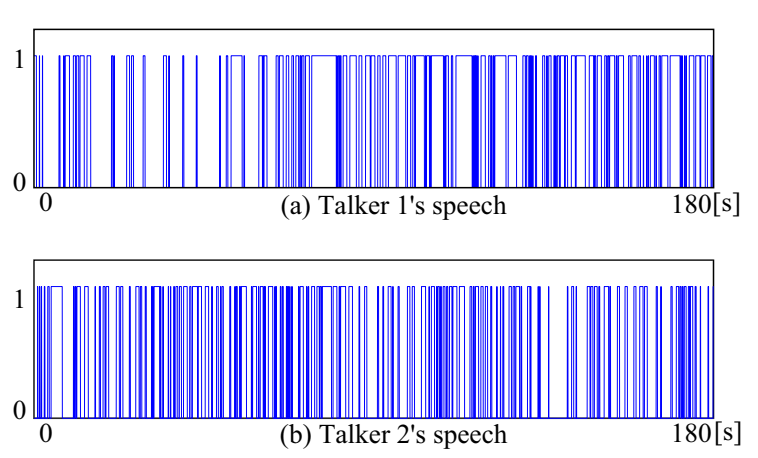

Number of subjects

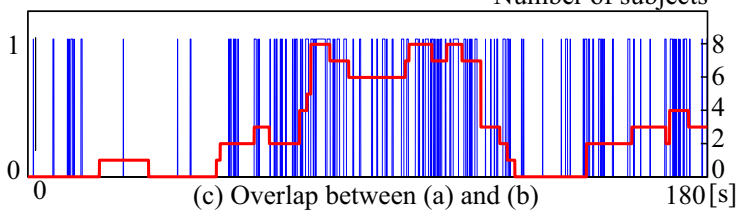

Fig. 5 Change in the relation between the speech overlap and the activated communication with time.

はなく，ある程度の時間幅を有することが示された．以上のことから，主観的に場の盛り上がりを感じる区間は， 笑い合いなどの両者の音声の重なりが生じる場面であると考えられる.

次に , コミュニケーション時における場の盛り上がりと対話者の音声の重なり (オーバラップ) との時系列関 係に着目して解析した .ここで, オーバラップに着目したのは, オーバラップと場の盛り上がりとの間に関連性 があることが報告されているからである ${ }^{(16)(17)}$. 音声データ $x(i)$ は , 16bit で量子化した最大振幅值 $( \pm 32767)$ が \pm 1 となるように正規化・絶対值化し，サンプリング周波数 $30 \mathrm{~Hz}$ で音圧が閾值を超えた場合を ON，光うでない 場合を OFF として，ON区間に対して 5/30 秒でハングオーバ (ON 区間を伸ばして短い OFF 区間を ON 区間に置 換) 処理を施して 2 值化した .ここで, 盛り上がっている場面では音量が大きくなることから ${ }^{(18)}$, 音声入力の有

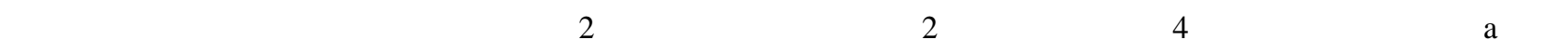
も高い闇值 A に設定することで, 音量の大きい部分が抽出されていることがわかる . 対話者相互のオーバラップ は以下の式 (1)を用いて算出した .

$$
\operatorname{overlap}(i)=x_{1}(i) \times x_{2}(i)
$$

$x_{1}(i):$ 対話者 1 の 2 值化した音声， $x_{2}(i)$ : 対話者 2 の 2 值化した音声

图 5 に実験 3 分間における対話者 1 の音声，対話者 2 の音声及びオーバーラップの時系列推移例を示す . 場の盛 り上がり加算波形が増加するとともにオーバラップの割合が増加し, 密になっていることがわかる . これは, 他 の3 組においても同樣の傾向が認められた . 㚇こで, オーバラップと場の盛り上がり加算波形との相関係数を求 めた結果，全 4 組の平均が 0.51 となったことから，場の盛り上がり区間とオーバラップとは正の相関関係にある ことが示された .

\section{3. 会話活性度推定モデル}

前章の場の盛り上がり特性解析から, アバタを介したコミュニケーションにおける場が盛り上がっていると判定 された区間では，主に笑い合っている場面が多く，対話者相互のオーバラップか頻出する結果が得られた .これら のことから，場の盛り上がりを感じる区間では，オーバラップが増加し，音声インタラクションが活性化してい るものと考えられる. 乥こで本研究では, これらの場の盛り上がり特性に基づいて, 発話音声からオーバラップ を算出し, 会話活性度を推定する会話活性度推定モデルを提案する . このモデルは, 対話者相互の発話音声の重 なりに基づき, 会話活性度（音声インタラクションにおける活性の度合い）を推定するものである．さらに，こ のモデルに基づく推定値から場の盛り上がっている状態を推定する . 


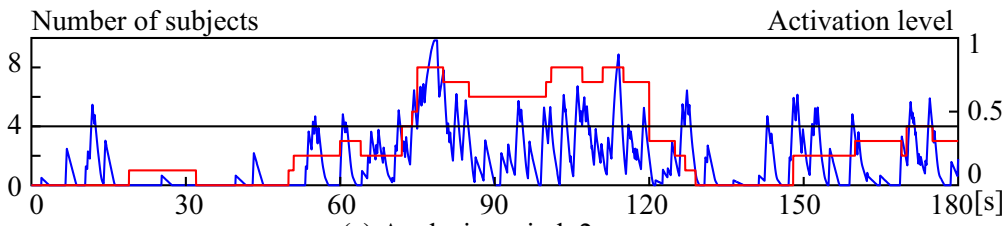

(a) Analysis period: $2 \mathrm{sec}$

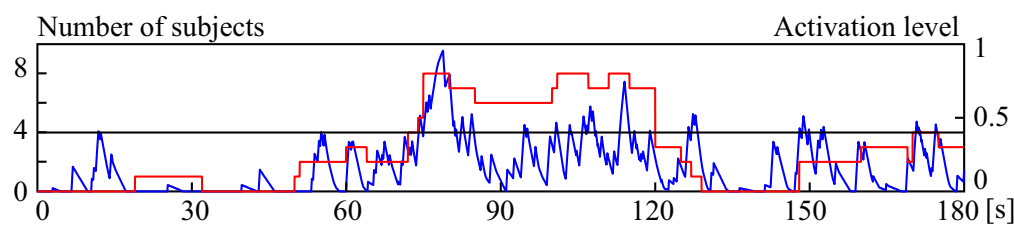

(b) Analysis period: $3 \mathrm{sec}$

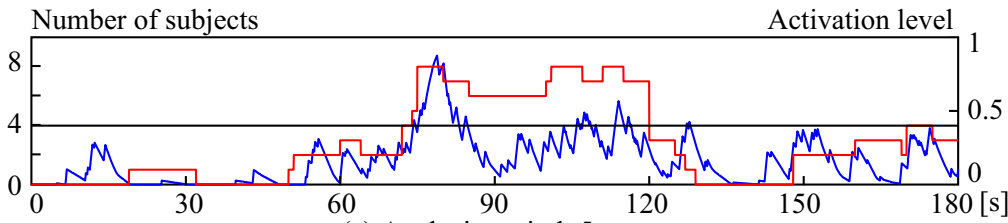

(c) Analysis period: $5 \mathrm{sec}$

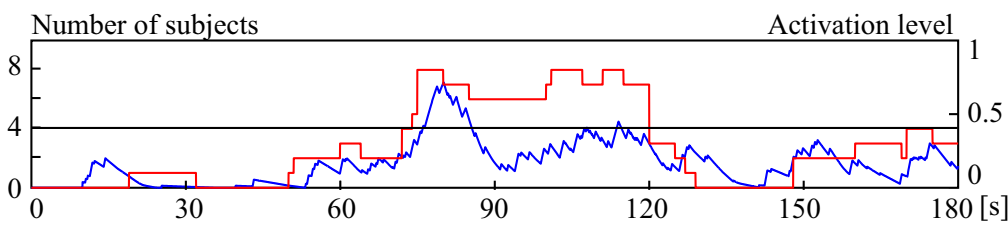

(d) Analysis period: $10 \mathrm{sec}$

Fig. 6 Change in the model-based estimated value with time.

\section{$3 \cdot 1$ 会話活性度推定モデル}

2.3 節の場の盛り上がり特性解析において，場の盛り上がりにはある程度の時間幅を有することが示された . こで本研究では, 重み付き移動平均により会話活性度の推定を試みる . まず , 現在のオーバラップの状態を式 (1) により算出する . 次に , 式 (2)のように算出したオーバラップに対して重み付き移動平均処理を行うことで, 会話 活性度を推定する . 現在のオーバラップに対して高い重み付けを行うことで, 推定值の立ち上がりを早めている．

$$
u(i)=\frac{\sum_{j=1}^{K}(K+1-j) \operatorname{overlap}(i-j)}{\sum_{j=1}^{K} j \times 0.01}
$$

$u(i)$ : 会話活性度,$K$ : const.

ここで, 移動平均処理における分析区間を 2 秒, 3 秒, 5 秒, 10 秒と变化させた場合における会話活性度推定値 の時系列変化例を図 6 に示す. 分析区間が 2 秒または 3 秒の場合では，推定値の立ち上がりが早く, 瞬間的な盛 り上がりを捉えるには有効であるが，推定值の変化が激しく，時間幅が短い．また，分析区間を 10 秒とした場合 では，場の盛り上がり区間として十分な時間幅を有するが，推定値の立ち上がりが遅いため突発的な盛り上がり に対応できない．分析区間が 5 秒の場合では，推定值の立ち上がりも早く，かつ盛り上がりの時間幅を有してい ることがわかる．乥こで，各分析区間の推定値を $x(i)$, 場の盛り上がり加算波形を $y(i)$ として , 式 (3) の相互相関 関数 $C(\tau)$ を用いて評価した .

$$
C(\tau)=\frac{\sum_{i=1}^{n-\tau}\left\{x(i)-\mu_{x}\right\}\left\{y(i+\tau)-\mu_{y}\right\}}{\sqrt{\sum_{i=1}^{n}\left\{x(i)-\mu_{x}\right\}^{2}} \sqrt{\sum_{i=1}^{n}\left\{y(i)-\mu_{y}\right\}^{2}}}
$$

$\mu_{x}, \mu_{y}: x, y$ の平均值, $n:$ デー夕数, $i:$ 描画フレーム, $\tau:$ 時間遅れ 
その結果，分析区間を 5 秒とした場合に相互相関関数 $C(\tau)$ の最大値が 0.90 となり最も高く評価された . また , 他 の 3 組においても同樣の傾向が見られたことから，本研究では移動平均処理における分析区間を 5 秒とした .

次に，会話活性度推定モデルによって推定された值から，予め設定した閾値に基づいて場が盛り上がっている 場面の推定を行う .この閾値については，以下のように選定を行った．まず，場の盛り上がり加算波形において過 半数 (4人) 以上の被験者が盛り上がっていると回答した区間を ON ，乥うでない区間を OFFとして，場が盛り上 がっている場面の 2 值化を行った . 次に，推定值に対して $0.0 \sim 1.0$ の範囲で閾值を 0.1 刻みで变化させ，推定值 が閾值を超えた場合を ON ，光うでない区間を OFF として推定值の 2 值化を行った . 推定值を 2 值化したデータ と場が盛り上がっている場面の 2 值化データについて相互相関関数 $C(\tau)$ を用いて評価した .ここでは, 分析区間 180 秒間として相互相関関数 $C(\tau)$ のずれ時間を前後最大 5 秒で評価した . 帯の結果，閾値を 0.4 とした場合に相 関值が 0.94 となり最も高く評価された . また，他の 3 組においても同樣の傾向が見られたことから，本研究では 推定閾値を 0.4 とした。

\section{$3 \cdot 2$ 会話活性度推定モデルの評価実験}

会話活性度推定モデルの妥当性を検討するためにモデル評価実験を行った . 実験手順は以下の通りである . ま ず, EVCOS を用いて被験者にシステムを試用させた後，日常対話を対象として自由対話実験を 3 分間行った。被 験者は場の盛り上がり解析実験とは異なる女子学生 2 人であった . 実験後 , 対話に参加していない被験者 8 人に実 験の動画を視聴させ，場が盛り上がっていると思われる区間の開始時刻と終了時刻を記録した .ここで，両対話 者本人か場の盛り上がりを感じる区間は対話不参加者においても同樣に判定される傾向が見られることから，本 実験では不参加者のみの主観評価を行った . また，実験中にリアルタイムに生成された会話活性度推定值は八ー ドディスクに記録した .

実験結果を図 7 に示す . 図 7 (a) は実験の動画から場が盛り上がっていると判断した被験者の場の盛り上がり加 算波形である. 图 7 (b) は対話者相互の発話音声からリアルタイムに生成された会話活性度推定値の時系列波形で ある. 図 7 (c) は分析区間を 30 秒として, 上記 (a), (b) の時系列データを相互相関関数 $C(\tau)$ で評価した結果であ る . 図より， $\tau=$ 約 2.5 秒付近に強い正の相関が確認できる . 光こで , 分析区間を 180 秒間として相互相関関数 $C(\tau)$ のずれ時間を前後最大 5 秒で評価した . 兴の結果，相互相関関数 $C(\tau)$ の最大值は 0.71 となり，提案する会 話活性度推定モデルの妥当性が示された。

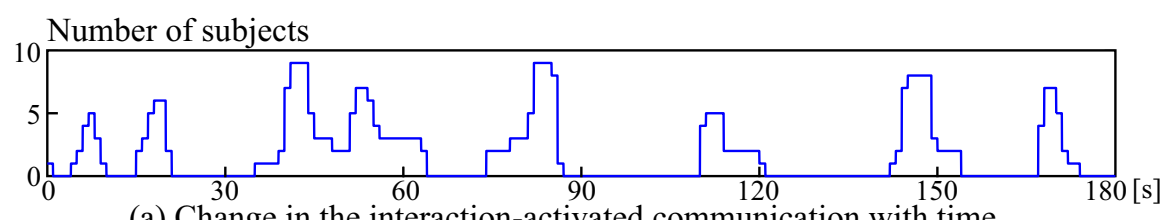

(a) Change in the interaction-activated communication with time, based on the number of subjects by whom the scene is subjectively selected as the activated communication scene.

Activation level

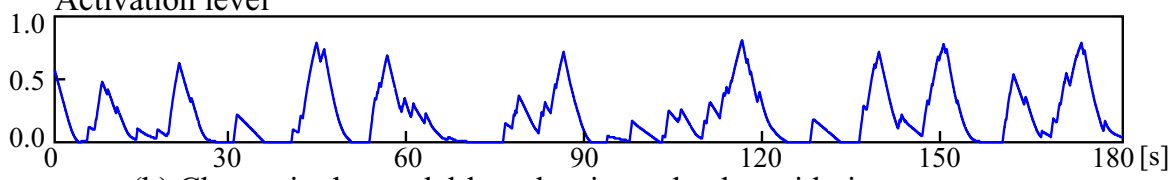

(b) Change in the model-based estimated value with time.

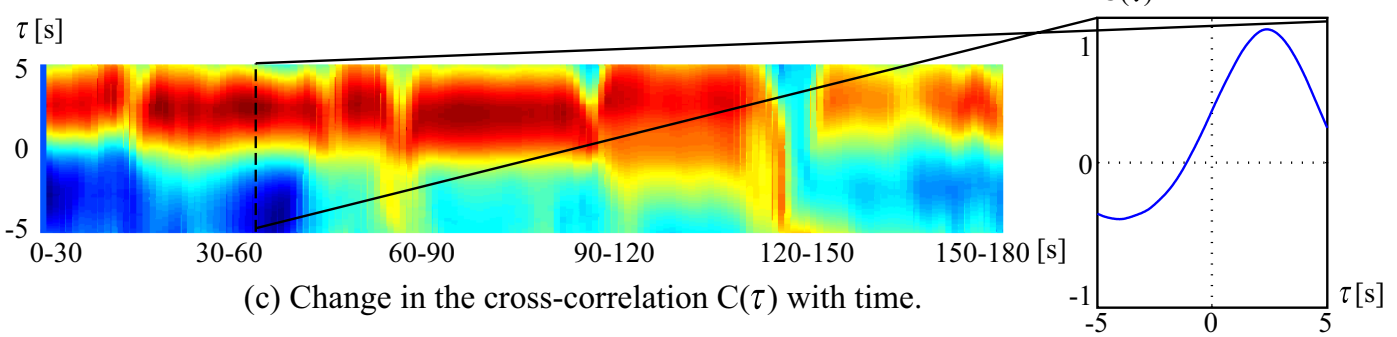

Fig. 7 Change in the cross-correlation $C(\tau)$ between the interaction-activated communication and the model-based estimated value with time. 


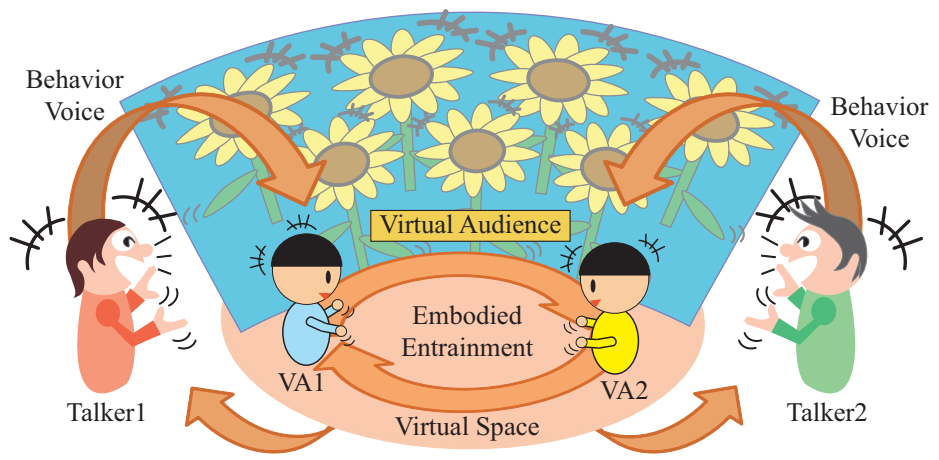

Fig. 8 Concept of the interaction-activated communication support system.

\section{4. 会話活性度推定モデルを付与した場の盛り上がり支援システム}

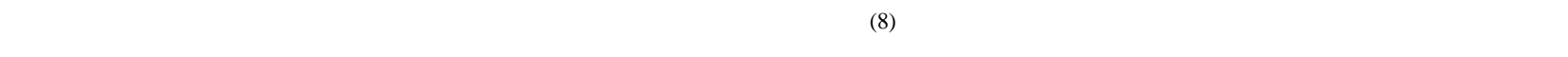
り上がりを支援する身体的コミュニケーションシステムを開発した．

\section{$4 \cdot 1$ コンセプト}

会話活性度推定モデルを仮想観客インタフェースに適用した場の盛り上がり支援システムのコンセプトを図 8 に 示す . 仮想観客は対話者の発話音声に基づいてうなずきなどの引き込み動作を行い , バーチャル空間内に身体的引 き込み ${ }^{(7)}$ を誘発させる .この身体的引き込みによって場の盛り上がりや一体感が向上し，さらに会話活性度推定 モデルによって場の盛り上がりが推定され，仮想観客が引き込み動作だけでなく盛り上がり動作を行う. 対話者は 場の盛り上がりを実感しつつ，仮想観客と一体となってインタラクションが向上する ${ }^{(19)}$.とくに，身体的引き込 み反応と場の盛り上がりを統合して提示することで, 場を盛り上げる雰囲気をつくるメディア表現が可能となる．

$4 \cdot 2$ システム開発

本研究では, 場が盛り上がっている場面での仮想観客の盛り上がり動作を構筑するために，場の盛り上がりの 典型として笑い動作に着目した。

4.2.1 笑い動作における呼気段落区分の解析

まず，笑い動作における呼気段落区分に着目し，男性 12 人，女性 4 人の笑い声をマイクを用いて $16 \mathrm{bit} 11 \mathrm{kHz}$ でサンプリングした . 次に , 得られた音声データに対して 2.3 節と同樣の 2 值化処理を行い, 笑い動作における呼 気段落区分を解析した . 弚の結果 , サンプリングした全員の呼気の 1 ユニット (On+Off) の平均時間は, $0.26 \pm 0.11$ 秒であった .

\subsection{2 仮想観客の盛り上がり 動作}

本研究では，インタラクション支援の観点から，観客参加型番組等の観客が盛り上がり場面で行う身体動作に 着目し，場が盛り上がっている場面で観客が振舞うと想定される代表的な 5 種類の身体動作を選定した（図 9).

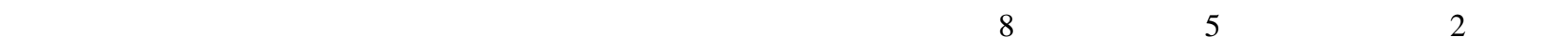
ンダムに選んで「盛り上がっている動作として好ましい」方を選択する比較を全ての組み合わせで行い，一対比 較を行わせた . ここで, 藤田らの研究によって, 盛り上がりに応じてアバタの身体動作の大きさや速度を増加さ せることで, 場の盛り上がりを表現できることが示されていることから ${ }^{(20)}$, 本研究においても笑い動作の呼気段 落区分である 0.26 秒の周期を用いて盛り上がり動作を生成した . 一対比較の結果を表 1 に示す. 表中の数字は各 種類の勝数，つまり各行の種類を選択した回数を表している.この結果に対して被験者による評価を定量的に評 価するために，Bradley-Terry モデルを想定した ${ }^{(21)}$.

$$
\begin{aligned}
& P_{i j}=\frac{\pi_{i}}{\pi_{i}+\pi_{j}} \\
& \sum_{i} \pi_{i}=\text { const } .(=100)
\end{aligned}
$$

$\pi_{i}: i$ の強さの量, $P_{i j}: i$ が $j$ に勝つ確率 


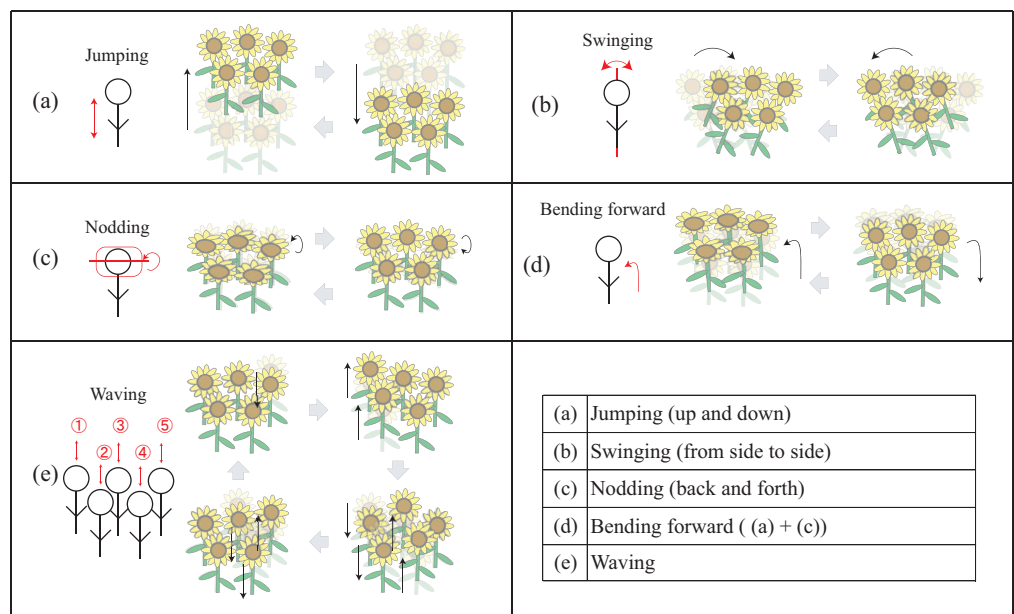

Fig. 9 Comparison of the virtual audience's behavior.

Table 1 Result of paired comparison.

\begin{tabular}{|c|c|c|c|c|c|c|}
\hline & (a) & (b) & (c) & (d) & (e) & Total \\
\hline (a) & & 8 & 4 & 2 & 8 & 22 \\
\hline (b) & 0 & & 0 & 1 & 4 & 5 \\
\hline (c) & 4 & 8 & & 1 & 7 & 20 \\
\hline (d) & 6 & 7 & 7 & & 7 & 27 \\
\hline (e) & 0 & 4 & 1 & 1 & & 6 \\
\hline
\end{tabular}

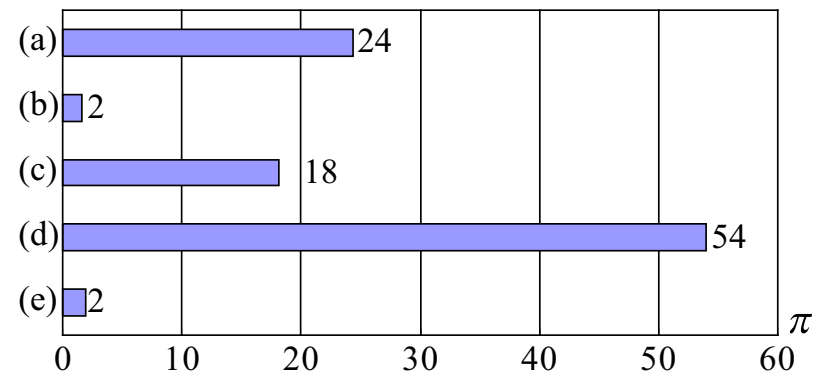

Fig. 10 Comparison of $\pi$.

$\pi_{i}$ は 5 種類の盛り上がり動作の好ましさ $(5$ モードの合計 100) を表し，このモデルを想定することにより，一 対比較に基づく好ましさを定量的に定めることができる . Bradley-Terry モデルより推定された盛り上がり動作の 好ましさ $\pi$ を図 10 に示す.このモデルの整合性を検討するために，適合度検定を行った結果，モデルは棄却され ず， $\pi$ の妥当性が保証された . 図 10 より，(d) 身を乗り出す動作が最も高く評価されていることがわかる . 以上の 結果より，仮想観客の盛り上がり動作は，会話活性度推定モデルで場の盛り上がりが検出された区間，笑い動作 の呼気段落区分である 0.26 秒の周期で, 身体全体が前に身を乗り出す動作を連続して行うものとした .

\section{$4 \cdot 3$ 場の盛り上がり支援システム}

仮想観客インタフェースに会話活性度推定モデルを適用し , 場の盛り上がり支援システムを開発した .システムの 概略を図 11 に示す. 本システムは, WindowsXP を搭載したPC (Hewlett-Packard hp workstation xw4200: Pentium4 $2.8 \mathrm{GHz}$ ，メモリ1GB，グラフィックボード NVIDIA Quadro FX3400）, 磁気センサ (POLHEMUS FASTRAK)，ヘッ ドセット (SONY DR-260DP) から構成される.VAの身体動作は, 対話者の頭部，背部，両手首に取り付けた 4 個

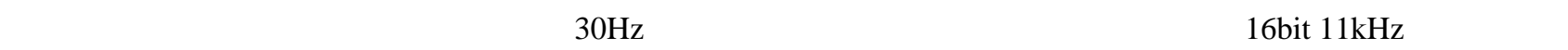
ングしている . 身体動作及び音声はギガビットイーサネットを経由して PC 間で送受信すると同時にハードディス クに記録している .バーチャル空間の構築は, Microsoft DirectX 9.0 SDK Update (Summer 2003) を用い, 描画速 度は30fpsである。

仮想観客であるひまわり型 $\mathrm{CG}$ キャラクタは, 音声入力がない場合であっても自然な摇らぎ動作を行うが, 音声 が入力されると聞き手としてうなずきや身体動作などの引き込み動作を行う．このときのうなずき動作は, 先行研 究の知見を基に，角速度 $0.03 \mathrm{rad} / \mathrm{frame}$ で花の部位が前後方向の回転運動を行うものとした ${ }^{(22)}$. また身体動作は， 角速度 $0.0125 \mathrm{rad} /$ frame で葉先を上下に摇らすものとした . 摇らぎ動作は, 生命感を与える瞬き反応モデル ${ }^{(23) を ~}$ 用い，うなずきを基点として指数分布させた . さらに , 会話活性度推定モデルに基づいて , 両対話者のオーバラッ プから推定された会話活性度が閾値を越えた場合に，仮想観客は盛り上がり動作を行う．この盛り上がり動作は， 予備実験の知見を基に, 身体全体が角速度 $0.012 \mathrm{rad} / \mathrm{frame}$ で $0.12 \mathrm{rad}$ までの身体全体が前に身を乗り出す動作を 行う.さらに, 角速度 $0.04 \mathrm{rad} / \mathrm{frame}$ で $0.12 \mathrm{rad}$ までの範囲内で複数の葉先を左右に摇らすことで, 躍動感のあ 


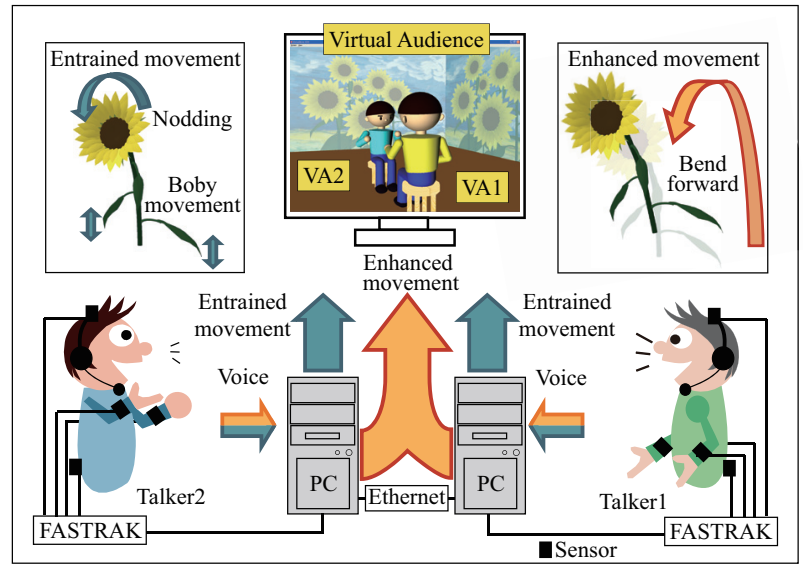

Fig. 11 Setup of the system.

る動作を生成している．これら引き込み動作と盛り上がり動作を光れ午れ排他的に実行するのではなく，両動作 を合成することで，身体的引き込みの効果を損なうことなく場が盛り上がっている䨌囲気を生成している．なお， 予備実験の際に会話活性度推定モデルに伴う盛り上がり動作の 2.5 秒程度の遅延については，「観客に盛り上がり が伝播しているようだった」等のコメントにより，遅延に対する違和感がないことを確認している．

\section{5. コミュニケーション実験}

\section{$5 \cdot 1$ 実験概略}

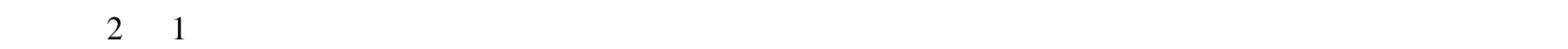
デオカメラにより録画した（図 12）．本実験では，日常対話を想定した自由対話実験と，会議などの話し合いを 想定した合意形成対話実験を行った . 自由対話実験での対話内容は日常の談話とした . 合意形成対話実験におけ る対話内容は表 2 に示す goo ランキング ${ }^{(24)}$ 調べによる , 各ランキングにおける上位 4 項目の中から 1 3 位の順 位を予想するものとした . 比較モードは, 先行研究により，うなずきなどの引き込み動作の有効性をすでに確認 しているため ${ }^{(8)}$, 自由対話実験では仮想観客が引き込み動作を行う「引き込み動作」と引き込み動作と盛り上が り動作を行う「併用動作」とした．合意形成対話実験では，本システムの顕著な有効性を検証するために，仮想 観客が動作を行わない「動作なし」を基準として提案システムである「併用動作」を比較した . 被験者は 18〜24 歳までの同性同士の男性 10 組，女性 10 組の計 40 人であった .

\section{2 実験手順}

まず, システムを 3 分間試用させた . 帯の後 , 各モードで 3 分間ずつ計 6 分間の自由対話実験を行わせた . 次 に，各モードで時間制限を設けずに合意形成対話実験を行わせた .ここでは，2 人の間で予想順位が一致するまで 対話を続けさせた . 最後に，「使用したい」の観点から二者択一の一対比較を行わせた . 各対話終了後, 7 段階に

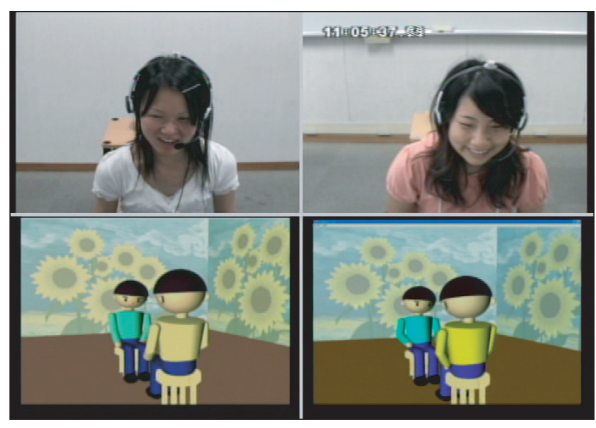

Fig. 12 Example of communication scene using the system.
Table 2 Ranking of conversational topics in a consensus building.

\begin{tabular}{|l|l|}
\hline $\begin{array}{l}\text { The favorite competition } \\
\text { ranking of an athletic meet }\end{array}$ & $\begin{array}{l}\cdot \text { Throwing-ball game } \\
\cdot \text { Mock cavalry battle } \\
\cdot \text { Relay } \\
\text { Tug-of-war }\end{array}$ \\
\hline $\begin{array}{l}\text { The last homework ranking } \\
\text { of the summer vacation that } \\
\text { always remained at elementary } \\
\text { school }\end{array}$ & $\begin{array}{l}\cdot \text { Book report } \\
\cdot \text { Independent research } \\
- \text { Diary }\end{array}$ \\
\hline
\end{tabular}


よる官能評価（中立０）を自由対話実験で「楽しさ」「対話しやすさ」「場の盛り上がり」「好み」アバタを介して の相手との「一体感」「安心感」の 6 項目，合意形成対話実験では「満足感」を追加した 7 項目のアンケートを行 わせた . 各モードの提示順および合意形成対話の話題は順序効果を考慮して組ごとにランダムとした .

\section{5 .3 官能評価結果}

7 段階評価結果を図 13 に示す.図には平均値と光の標準偏差を示している.自由対話実験において，「引き込 み動作」と「併用動作」を比較した結果，Wilcoxonの符号順位検定により「楽しさ」場の盛り上がり」の項目

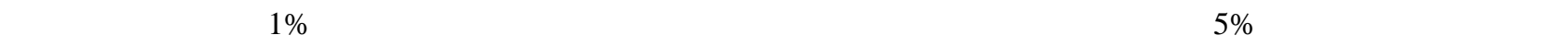
(図 13(a)）.さらに，合意形成対話実験では全ての項目において有意水準 1\%で有意差が認められ，併用動作」が 「動作なし」に対して極めて高く評価された (図 13(b))．

次に，一対比較実験の結果を図 14 に示す.自由対話実験では，併用動作が 40 人中 33 人 (82.5\%) の被験者に支 持された .さらに，合意形成対話実験では，併用動作が 40 人中 37 人 (92.5\%) の被験者に支持された .

以上の結果は，場の盛り上がりを視覚提示することによるコミュニケーション支援への有効性を示している．

\section{4 行動解析結果}

対話における場の盛り上がりを会話活性度推定モデルから算出された推定值に着目して解析を行った . 各実験 における会話活性度推定モデルの推定值の平均值を式 (6)によって評価した (図 15) . 自由対話実験において，「引 き込み動作」と「併用動作」を比較した結果， $\mathrm{t}$ 検定により有意水準 1\%で有意差が認められ，「併用動作」が「引 き込み動作」に対して会話が活性している割合が高かった .一方 , 合意形成対話実験では統計的な有意差は認め られなかった。

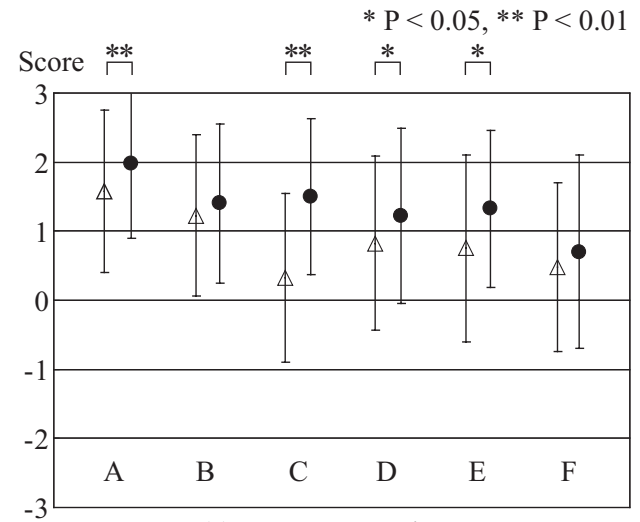

(a) Free conversation.

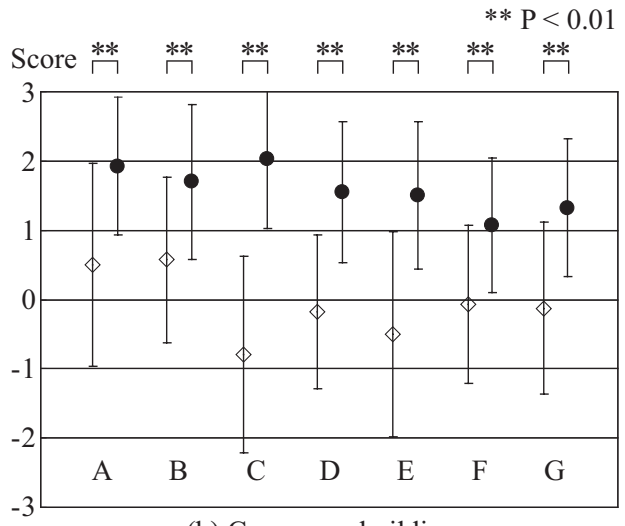

(b) Consensus building.

$$
\triangle \text { entrained mode } \bullet \text { combinational mode }
$$

$\diamond$ static mode $\bullet$ combinational mode

A: Enjoyment B: Interaction C: Excitement
D: Preference E: Unity
F: Relief
G: Satisfaction

Fig. 13 Questionnaire-based sensory evaluation.

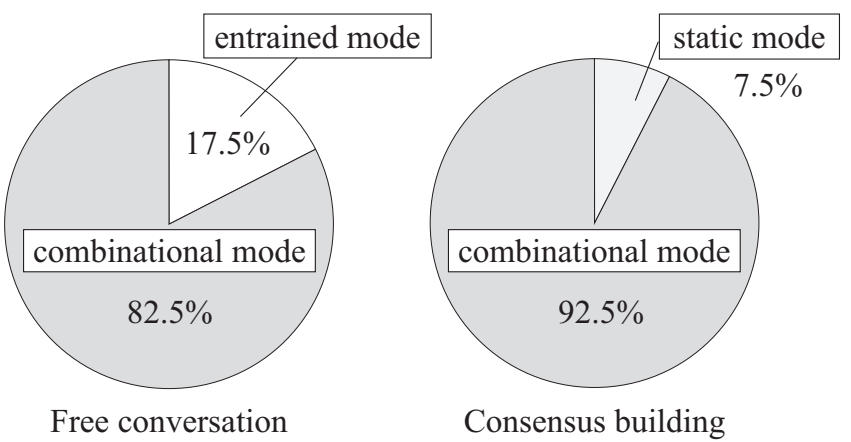

Fig. 14 Paired comparison. 


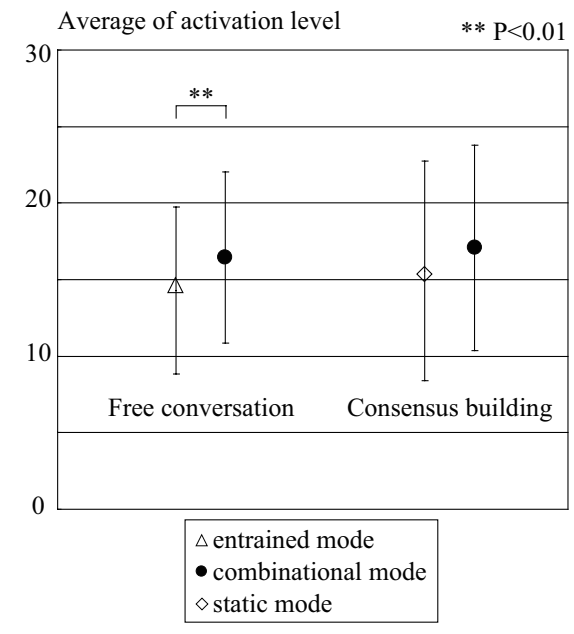

Fig. 15 Activated level in each experiment.

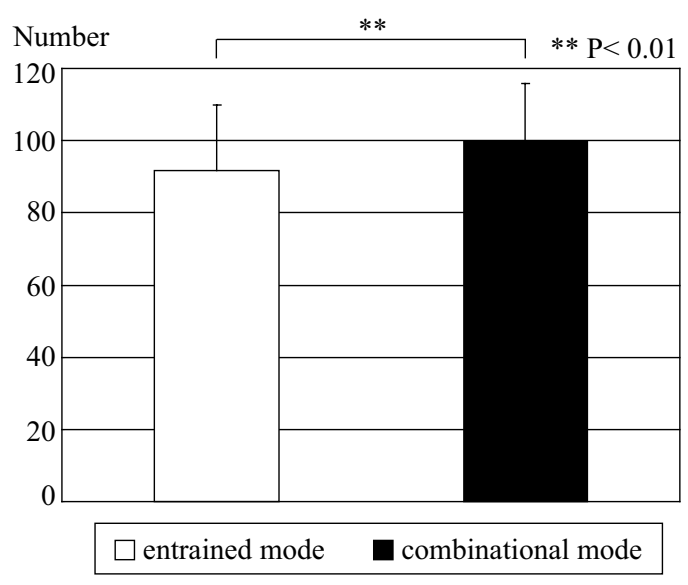

Fig. 16 Number of nods by the virtual audience during free conversation.

Average of activation level $=\frac{1}{N} \sum_{i=1}^{N} u(i)$

$u(i)$ : 会話活性度, $N$ : データ数

また，自由対話実験における仮想観客が行ったうなずき動作回数を図 16 に示す「引き込み動作」と「併用動作」 を比較した結果， $\mathrm{t}$ 検定により有意水準 $1 \%$ で有意差か認められた . 両モードともに身体的引き込み反応を提示し ているにも拘わらず，うなずき動作の回数が多くなり，発話の促進効果が認められた．

\section{5 考察}

先行研究において，日常対話を対象とした自由対話実験では，仮想観客がうなずきなどの引き込み動作を行う ことで,「対話しやすさ」や「安心感」が向上することが示されている ${ }^{(8)}$.これに対して, 本研究で仮想観客が引 き込み動作と盛り上がり動作を行った場合では，対話しやすさ」「安心感」については引き込み動作のみと同程度 であったものの「楽しさ」「場の盛り上がり」「好み」「一体感」の項目において高く評価された .さらに，官能評 価だけでなく行動解析においても会話活性度の向上やうなずき動作の回数が増加するなど，インタラクションの 促進を高める結果となった .これは，引き込み動作がコミュニケーション場に身体的リズムの引き込みを促して いるのに対して，盛り上がり動作はさらにこの身体的引き込み効果に加えて，仮想観客を含めたダイナミックな コミュニケーション場の情報を対話者にフィードバックし，光れらの相乗効果がコミュニケーションの活性化をも たらしたものと考えられる .

合意形成対話実験では，先行研究において仮想観客の動作モードとして「引き込み動作」と「動作なし」との 比較を行った結果，インタラクション支援効果か認められたことから，本研究においても同樣の効果か期待され るため,「併用動作」と「動作なし」との比較を行った．弚の結果，「場の盛り上がり」「一体感」「満足感」などの 全ての項目において極めて高く評価された .これは，仮想観客が身体的引き込みにより身体性の共有を促すだけ でなく，場の盛り上がりを反応動作に反映させることで, 対話者はインタラクションの樣態 (場の盛り上がり) と コミュニケーション場との関連付けが容易に行いやすくなり，一体感が向上したものと考えられる．

また，先行研究において，アバタの身体動作のみを反映させたモードと，うなずき反応モデルによって生成さ れたうなずき動作の動作タイミングを時間的にシフトさせ , アバタの動作頻度を高めたモードを用いてインタラ クション支援を検討した . 弚の結果, 動作頻度を高めたモードでは, 身体動作のみを反映させたモードに比べて 「場の盛り上がり」,「一体感」「好み」等の項目において評価が低くなることが示されている ${ }^{(25)}$.すなわち，単に 動作量を増加させるだけでなく，インタラクションを考慮したシステム設計でなければ，コミュニケーション支援 に繋がらないことが示されている．本研究で開発したシステムは, 自由対話実験および合意形成対話実験の両実 
験において高く評価されていることから，場全体とのかかわりが実感でき，コミュニケーション支援に繋がった ものと考えられる .

以上のことから，開発したシステムが場の盛り上がりを支援し，コミュニケーション・インタラクションを促 進することから , システムの有効性が示された .

\section{6. おわり $わ$}

本研究では, 身体的バーチャルコミュニケーションシステムを用いてアバタを介したコミュニケーションにおけ る場の盛り上がり特性を解析し，弚の解析結果に基づいて会話の活性度を推定する会話活性度推定モデルを提案 した . 次に , 提案モデルを仮想観客インタフェースに適用し, 身体的引き込み反応に加え，場の盛り上がりを支 援する身体的コミュニケーションシステムを開発した .さらに, 開発したシステムを用いてコミュニケーション 実験を行った . 兴の結果 , 場の盛り上がりを把握しつつ, 楽しさや一体感が向上するなど円滑なコミュニケーショ ンが実現され，提案モデルおよび開発したシステムの有効性を示した .

今後は, 場の盛り上がり評価の確立や盛り上がっていない状況下での活性化モデルの開発，さらに場の盛り上 がりに応じて仮想観客の振舞いを変化させ , 人と人との身体的引き込みの度合いを制御するコミュニケーション システムの構筑など , 各種条件下で分析評価する予定である .

謝 辞

本研究の一部は科学研究費 $(24700536,22300045)$ の助成を受けたものである .

文献

（1）駒谷昇一, 山川修, 中西通雄, 北上始, 佐々木整, 晹瀬裕昭, 情報とネットワーク社会 (2011), pp. 2-25, オーム社.

(2) CyberAgent, Inc., “アメーバピク”, アメーバピグ, http://pigg.ameba.jp/ (参照日 2012 年 4 月 15 日) .

(3) Miyajima, T. and Fujita, K., "Control of Avatar's Facial Expression Using Fundamental Frequency in Multi-User Voice Chat System", Proceedings of The 6th International Conference on Intelligent Virtual Agents (2006), p. 462.

(4) Kusumi, T., Ogura, K., Miura, A., "The Development of a Positive Community using Virtual Space for Cancer Patients", Proceedings of Second International Symposium on Universal Communication (2008), pp. 490-493.

(5) Courty, N, Breton, G., Peld, D., "Embodied in a Look: Bridging the Gap between Humans and Avatars", Proceedings of The 4th International Conference on Intelligent Virtual Agents (2003), pp. 111-118.

(6) Amy, L. B. and Soyoung K., "The Effects of Agent Nonverbal Communication on Procedural and Attitudinal Learning Outcomes", Proceedings of The 8th International Conference on Intelligent Virtual Agents (2008), pp. 208-214.

(7) Condon, W. S., Sander, L. W., "Neonate Movement is Synchronized with Adult Speech”, Science, Vol. 183 (1974), pp. 99-101.

（8）瀬島吉裕，石井裕，渡辺富夫，“アバタコミュニケーション支援のための音声駆動型身体的引き込み絵画を用いた仮想観 客システム”, 日本機械学会論文集 C 編, Vol. 78, No.786 (2012), pp. 523-534.

(9) 日本笑い学会, 笑いの世紀 (2009), pp. 48-51, 創元社.

(10) Björn, H., Maurizio, M. and Catherine, P., "Implementing Expressive Gesture Synthesis for Embodied Conversation Agents", Gesture Workshop 2005 (2005), pp.188-199.

(11) 前田貴司, 高嶋和毅, 梶村康祐, 山口德郎, 北村喜文, 岸野文郎, 前田奈穂, 大坊郁夫, 林良彦, “3 人会話における非言 語情報と「場の活性度」に関する検討”, 電子情報通信学会技術研究報告, Vol. 109, No. 27 (2010), pp. 73-78.

(12) 守屋悠里英, 田中貴紘, 宮島俊光, 藤田欣也 , “ボイスチャット中の音声情報に基づく会話活性度推定方法の検討”, ヒュー マンインタフェース学会論文誌, Vol. 14, No.3 (2012), pp. 57-66. 
(13) Watanabe, T., Ogikubo, M., Ishii, Y., "Visualization of respiration in the embodied virtual communication system and its evaluation”, International Journal of Human-Computer Interaction, Vol. 17, No. 1 (2004), pp. 89-102.

(14) 石井裕, 渡辺富夫 , “身体的バーチャルコミュニケーションシステムを用いた VirtualActor の対話配置の評価”，ヒューマ ンインタフェース学会論文誌, Vol. 4, No. 2 (2002), pp. 43-50.

(15) 徳久良子, 寺嶌立太 , “杂隹談における発話のやりとりと盛り上がりの関連”, 人工知能学会論文誌, Vol. 21, No. 2 (2006), pp. 133-142.

（16）伊藤秀樹，重野真也，西本卓也，荒木雅弘，新美康永，“対話における雰囲気の分析”, 情報処理学会研究報告, Vol. 2002, No. 10 (2002), pp. 103-108.

(17) 西村良太 , 北岡教英, 中川聖一, “対話における韻律変化・タイミングのモデル化と音声対話システムへの適用”, 人工知 能学会言語・音声理解と対話処理研究会, No. 48 (2006), pp. 37-42.

（18）関口一樹, 小杉信, 向井信彦, “映像と音情報を用いた野球中継の自動インデクシング”, 電子情報通信学会技術研究報告 , Vol. 106, No. 398 (2006), pp. 41-46.

(19) Sejima, Y., Ishii, Y., Watanabe, T., "A Virtual Audience System for Enhancing Embodied Interaction Based on Conversational Activity", Proceedings of the 14th International Conference on Human-Computer Interaction (HCII2011), Human Interface, Part II, HCII 2011, LNCS 6772 (2011), pp. 180-189.

（20）佐伯悠子, 田中貴紘，藤田欣也，“会話活性度に基づくアバタ動作の統一的制御方法の検討”, 電子情報通信学会技術研究 報告, Vol. 109, No. 28 (2009), pp. 71-74.

(21) 竹内啓, 現象と行動のなかの統計数理 (1978), pp. 133-148, 新曜社.

(22) 吉田真章, 渡辺富夫, 山本倫也 , “3DCG オブジェクトを用いた音声駆動型身体的引き込みシステム”, ヒューマンインタ フェース学会論文誌, Vol.9, No. 3 (2007), pp. 87-96.

(23) Watanabe, T., Yuuki, N., "A Voice Reaction System with a Visualized Response Equivalent to Nodding", Advance in Human Factors/Ergonomics, 12A (1989), pp. 396-403.

(24) NTT Resonant Inc., “goo ランキング”, goo ランキング, http://ranking.goo.ne.jp/ (参照日 2008 年 11 月 3 日).

（25）瀬島吉裕，渡辺富夫，山本倫也，“うなずき反応モデルを重畳した VirtualActor を介する身体的コミュニケーションの合 成的解析”, 日本機械学会論文集 C 編, Vol. 75, No. 758 (2009), pp. 169-178. 